\title{
Tree rings of Scots pine (Pinus sylvestris L.) as a source of information about past climate in northern Poland
}

\author{
Marcin Koprowski • Rajmund Przybylak • \\ Andrzej Zielski • Aleksandra Pospieszyńska
}

Received: 1 June 2010 /Revised: 16 November 2010 /Accepted: 17 November 2010 / Published online: 21 December 2010

(C) The Author(s) 2010. This article is published with open access at Springerlink.com

\begin{abstract}
Scots pine (Pinus sylvestris) is a very common tree in Polish forests, and therefore was widely used as timber. A relatively large amount of available wood allowed a long-term chronology to be built up and used as a source of information about past climate. The analysis of reconstructed indexed values of mean temperature in 51year moving intervals allowed the recognition of the coldest periods in the years 1207-1346, 1383-1425, 1455-1482, 1533-1574, 1627-1646, and 1694-1785. The analysis of extreme wide and narrow rings forms a complementary method of examining climatic data within tree rings. The tree ring widths, early wood and late wood widths of 16 samples were assessed during the period 1581-1676. The most apparent effect is noted in the dry summer of 1616 . According to previous research and our findings, temperature from February to March seems to be one of the most stable climatic factors which influenced pine growth in Poland. Correlation coefficients in the calibration and
\end{abstract}

\footnotetext{
M. Koprowski $(\bowtie)$

Laboratory of Dendrochronology,

Institute of Ecology and Environment Protection,

Nicolaus Copernicus University,

Gagarina 9,

87-100, Toruń, Poland

e-mail: koper@umk.pl

R. Przybylak $\cdot$ A. Pospieszyńska

Department of Climatology, Institute of Geography,

Nicolaus Copernicus University,

Gagarina 9,

87-100, Toruń, Poland
}

\section{A. Zielski}

Faculty of Geology, Geophysics and Environmental Protection, University of Science and Technology,

al. Mickiewicza 30,

30-059, Kraków, Poland validation procedure gave promising results for temperature reconstruction from the pine chronology.

Keywords Dendrochronology · Dendroclimatology · Climate reconstruction. Scots pine

\section{Introduction}

Knowledge about past climate is becoming increasingly important. The issue of global warming in recent decades, and its causes, may be better understood when past climates are better known. Multi-proxy methods, used recently for temperature reconstructions, corrected and improved our understanding of climate changes. Our state-of-the-art knowledge concerning global climate changes in the last millennium was summarized by Jones and Mann (2004). For Poland, a similar summary was presented by Przybylak et al. (2005, 2010) The authors used historical sources, dendrochronological, and geothermal data, to investigate the temperature changes from the sixteenth to the twentieth centuries.

Dendroclimatological research in northern Poland using Scots pine (Pinus sylvestris) tree-ring widths has been conducted, e.g., by Zielski (1997), and Zielski and Sygit (1998). The authors stated that February and March air temperature is the most important influence on tree-ring growth in the northern part of the country. Generally similar results were also found for the north-western part, where the growth of trees was correlated with air temperature during the periods: February-March, February-April, February, JanuaryMarch, depending on site location (Cedro 2001). February and March air temperature also play an important role in the Małopolska Region (Lesser Poland) (Szychowska-Krapiec 2010), Lower Silesia and Sudety mountains (Feliksik and Wilczyński 2000; Wilczyński and Skrzyszewski 2002). 
A few long-term pine chronologies were constructed for Poland, e.g. KUJAWPOM (1168-2000) for KuyavianPomerania (Zielski and Krapiec 2004), or for southern Poland from 1091 to 2006 (Szychowska-Krapiec 2010), each of which can be used in climate reconstruction. The key assumption is that such chronologies in most cases reflect environmental conditions. Some factors, such as frost or summer drought, may have an immediate effect on ring width, other factors such as winter drought may have a delayed effect on tree-ring widths, since the growing tissue is dormant. The effect of different factors is seen as a variation in ring size and structure, which may change systematically, or vary slowly throughout the life of the tree (Fritts 1976). We hypothesize that growth is controlled mainly by climate, and therefore we have investigated the influence of mean monthly temperatures and monthly precipitation totals on tree-ring growth.

This research is part of a broader project which includes geothermal and historical data as a source of information about climate in the last millennium (funded by a grant from the Polish Ministry of Science and Higher Education for years 2007-2010). The climate fluctuations in Poland need to be better recognized, especially nowadays when discussion about global warming caused by human activity is very vivid. Reconstructions of climate for lowland areas in Poland are rarely made, as discussed in detail by Zielski et al. (2010).

The main aim of this work was first to determine which climatic parameter can best be reconstructed, and then to use this in new reconstructions. The next step in the research was to determine the pointer years in the KUJAWPOM chronology and of the selected period for historical wood coming from a post-Cistercian church. This site was selected because the cross-correlations of samples from this area is very high, and in addition, Koronowo is quite a long way from the Vistula River which was used for wood transport. It was therefore assumed that the timber from Koronowo represented local trees, and is therefore valuable in the study of climate changes in the Kuyavia-Pomerania region. In our research, pointer years are defined as years in which extremely wide or narrow tree rings, late or early wood layers, were created. A further objective was to compare our chronology with selected European chronologies. Such a comparison allows the similarity of the Polish climate to the climate of neighboring regions to be determined.

\section{Materials and methods}

Living trees and the historical timber

The samples from living trees and cores from historical buildings were located in the Kuyavian-Pomerania region (Fig. 1). A total of 209 samples were taken: 98 cores from
55 living trees were extracted at $1.3 \mathrm{~m}$ above tree base using an increment borer and 111 samples were taken from 18 historical objects (Fig. 2) (Zielski and Krapiec 2004). The cores were prepared for measurement using standard dendrochronological procedures (Zielski and Krapiec 2004). The tree ring widths were measured to the nearest $0.01 \mathrm{~mm}$ by means of mechanical instrument with a computer registering the ring widths. The checks on crossmatching were carried out using COFECHA (Grissino-Mayer 2001) and TSAP (Rinn 2003) programs using the Student's $t$ test and the \% Gleichläufigkeit (\% GL) (Schweingruber 1983). Additionally, each sample was analyzed by means of the skeleton plot method (Schweingruber 1996).

Long-term chronology

The dplR program (Bunn 2008) was used to detrend the KUJAWPOM chronology. The interactive option allows the comparison of three different methods for detrending; the modified negative exponential curve, a cubic smoothing spline, and a horizontal line. The smoothing spline was chosen, which better reflects trends in the KUJAWPOM chronology. The use of different smoothing methods in some cases is also applied separately for each sample from the chronology (Esper and Gärtner 2001). The " $n$-year spline" is here fixed as $2 / 3$ the wavelength of $n$ years (Cook et al. 1990). The index is calculated by division. A residual version of the chronology was built by pre-whitening, performed by fitting an autoregressive model to the data, where the complexity of the model is selected by Akaike's information criterion (Bunn 2008). The R-project is opensource software and is part of the GNU project, which is similar to the $\mathrm{S}$ language. $\mathrm{R}$ can be considered as a different implementation of S. There are some important differences, but much code written for $\mathrm{S}$ runs unaltered under $\mathrm{R}(\mathrm{R}$ Development Core Team 2007).

\section{Climate influence and data filtering}

In order to investigate climate/growth relationships, the DendroCLIM 2002 programme was applied (Biondi and Waikul 2004). This program applies a bootstrap procedure to estimate the error using random sampling from the data. DENDROCLIM2002 uses 1,000 bootstrapped samples to compute response and correlation coefficients, and to test their significance at the 0.05 level (Biondi and Waikul 2004). Climate data from October of the previous year to September of the current year served as independent variables, and the residual chronologies for each site were used as dependent variables.

Mean monthly temperatures and monthly precipitation sums were collected from the Bydgoszcz meteorological station (from 1861 to 2000) belonging to the Institute of 


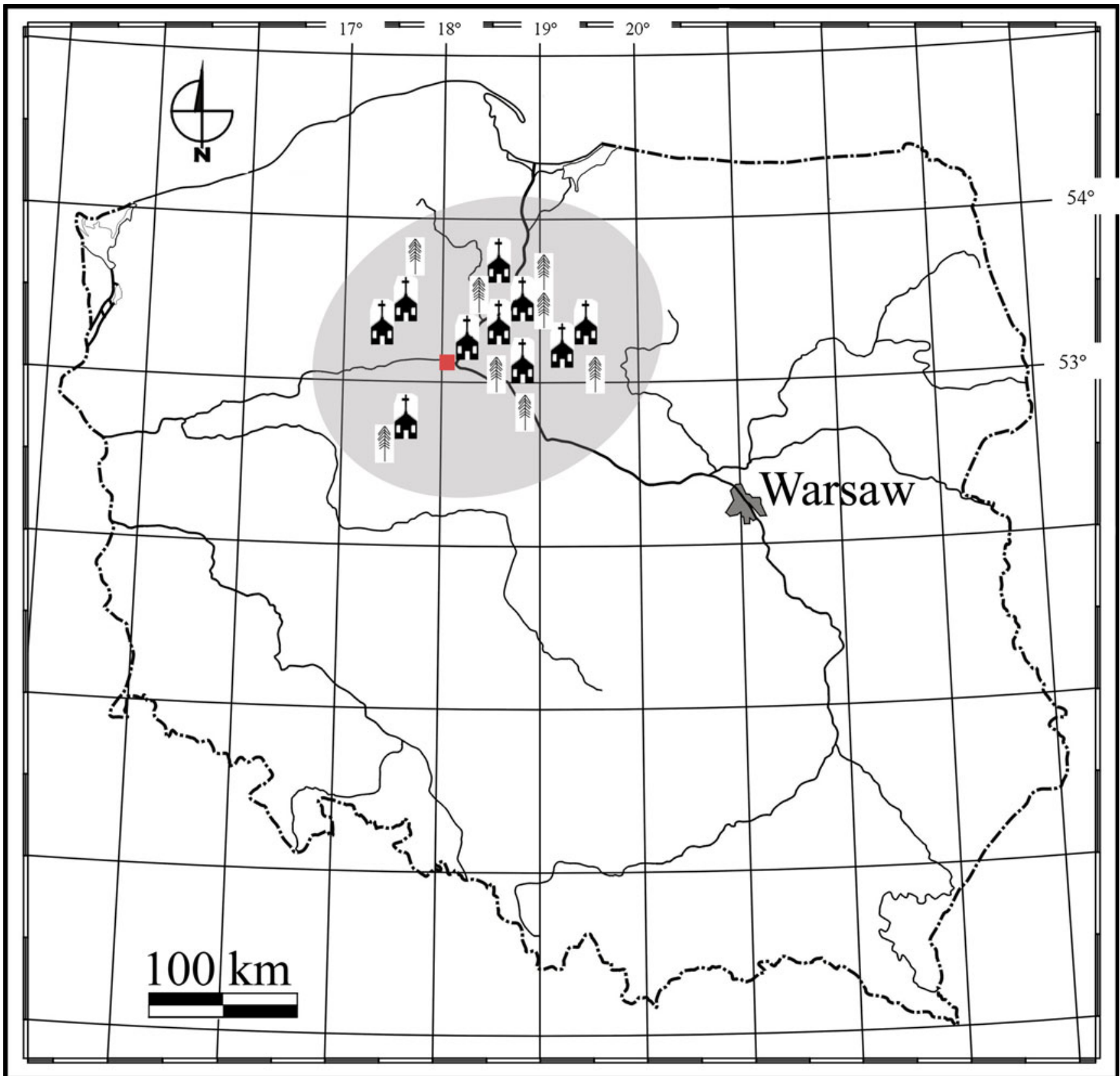

Fig. 1 Sites with living Scots pine (Pinus sylvestris) trees and historical objects which were the source of cores. Tree icon sites with living trees, church icon sites with historical objects, red square meteorological station in Bydgoszcz

Drainage and Grasslands (Figs. 1 and 3). The data from Bydgoszcz station are the most representative for the region and homogenized by Vizi et al. (2001)

Statistical calculations such as linear regression values for a regression model and correlations were calculated by means of R (R Development Core Team 2007; Verzani 2004). DplR (Bunn 2008) was used to filter the temperature data. A low frequency Hanning filter with a 51-year length weighting was applied, using the formula in dplR according to Oppenheim et al. (1999).
Pointer years

The timbers from a post-Cistercian church in Koronowo $\left(53^{\circ}\right.$ $\left.18^{\prime} 31.7^{\prime \prime} \mathrm{N}, 17^{\circ} 56^{\prime} 08.8^{\prime \prime} \mathrm{E}\right)$ were chosen for pointer year analysis. We selected this site because the cross-correlations of samples from this area are very high, and in addition Koronowo is quite a long way from the Vistula River which was used for wood transport. It was therefore assumed that the timber from Koronowo represented local trees, and is therefore valuable in the study of climate changes in the Kuyavia- 
Fig. 2 The replication of the tree-ring sequences in the KUJAWPOM chronology

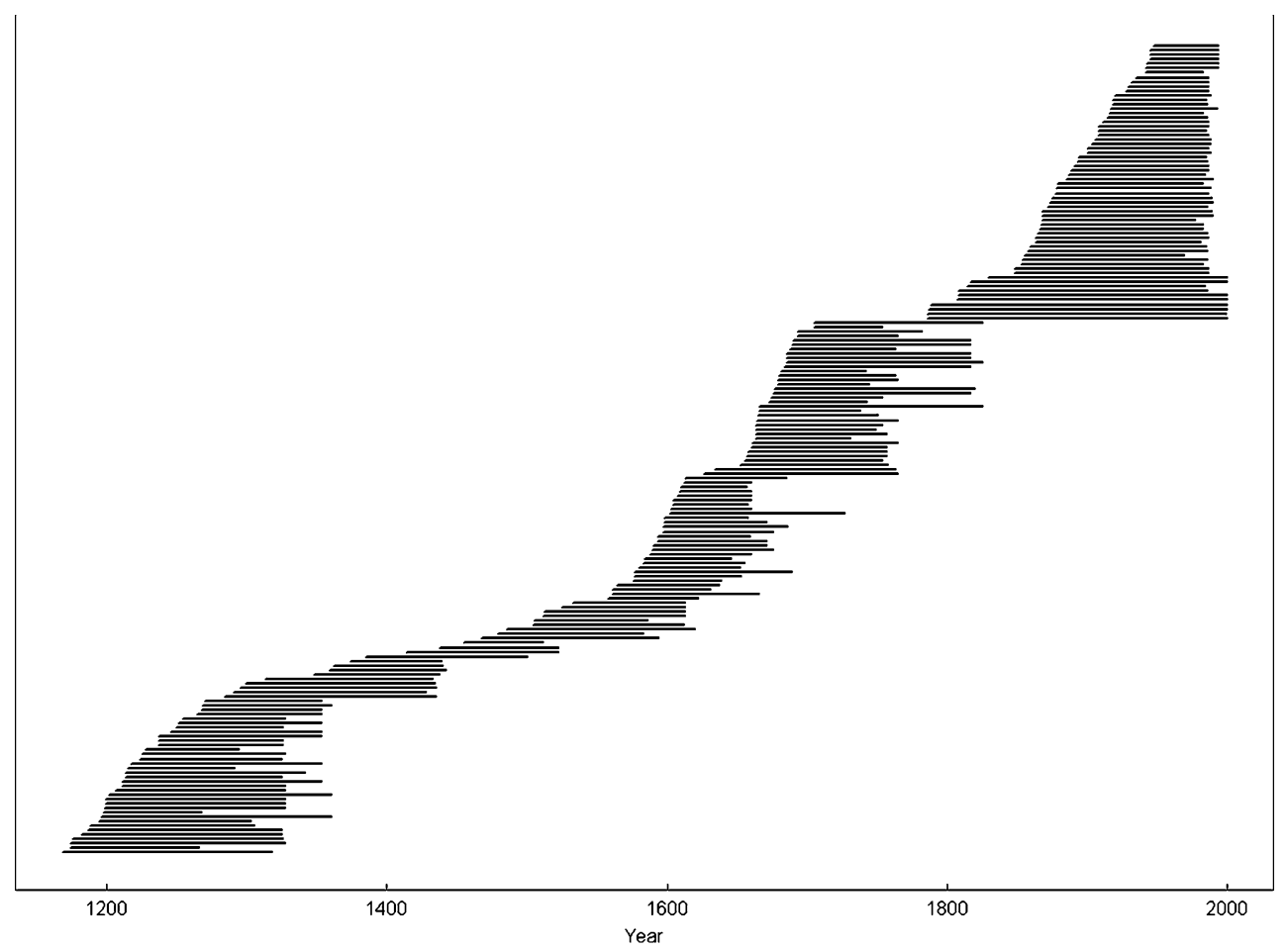

Pomerania region. The assumption of pointer year analysis is that extreme weather conditions significantly influence tree growth. The tree ring widths, early wood and late wood widths of 16 samples were taken into account. The time span is from

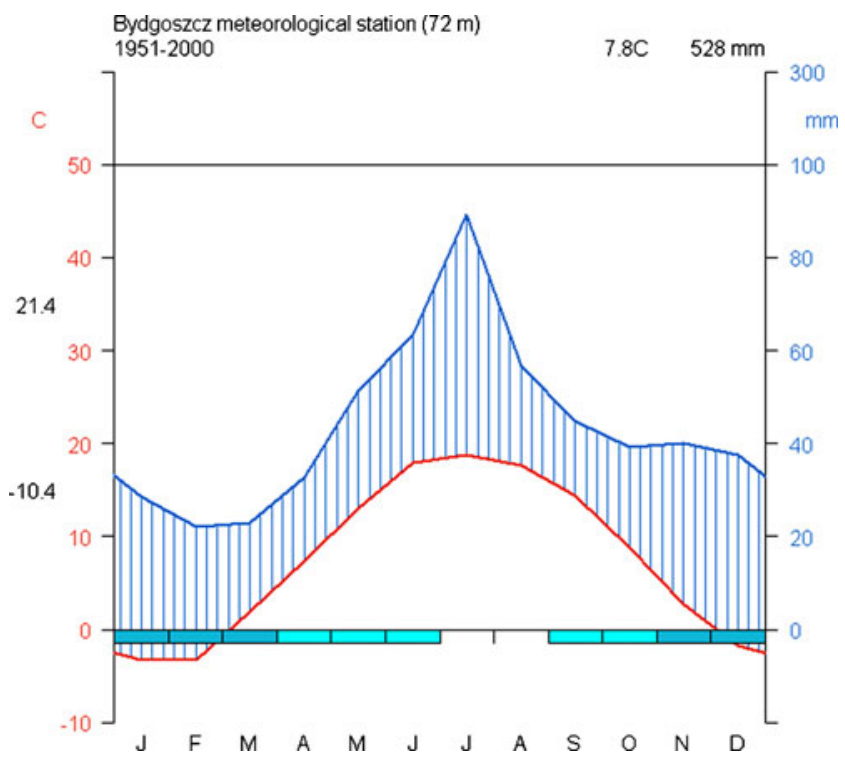

Fig. 3 Climate diagram of the meteorological station in Bydgoszcz. Each tick mark along the abscissa indicates a month, $J$ January, $F$ February, etc. The diagram shows the appearance of daily minimum temperatures below zero in blue bars below the horizontal line. Blue line a precipitation curve, red line temperature, $21.4^{\circ} \mathrm{C}$ mean daily max. temperature of the warmest month, $-10.4^{\circ} \mathrm{C}$ mean daily min. temperature of the coldest month. Upper right corner of the diagram annual average of temperature and annual precipitation sums
1581 to 1676 . In this case, we have measured tree rings, late wood and early wood using the same computer program as for tree-ring measurements. The chronology for this historical site covers the years 1581-1676. Pointer years were determined using a procedure which averages the values inside the time window (Meyer 1998-1999). The calculations were made using program WEISER (Gonzales 2001). We have also investigated the KUJAWPOM chronology in order to find pointer years in tree-ring widths.

\section{Results}

Climate/growth relationships - model

Values of the bootstrap correlation of tree-ring chronologies with mean monthly temperature and precipitation were calculated for the period 1861-2000. There was a positive effect of the mean monthly temperature for the current February and March and a negative influence of high temperature in June (Fig. 4). The precipitation in May, June and July positively influenced the radial growth of trees $(p<0.05)$ (Fig. 4). Mean temperature for February-March was used in the subsequent temperature reconstruction.

Climate/growth relationships- calibration, verification and reconstruction

The calibration period was based on the years 1861-1930. The correlation for the mean value of February-March 

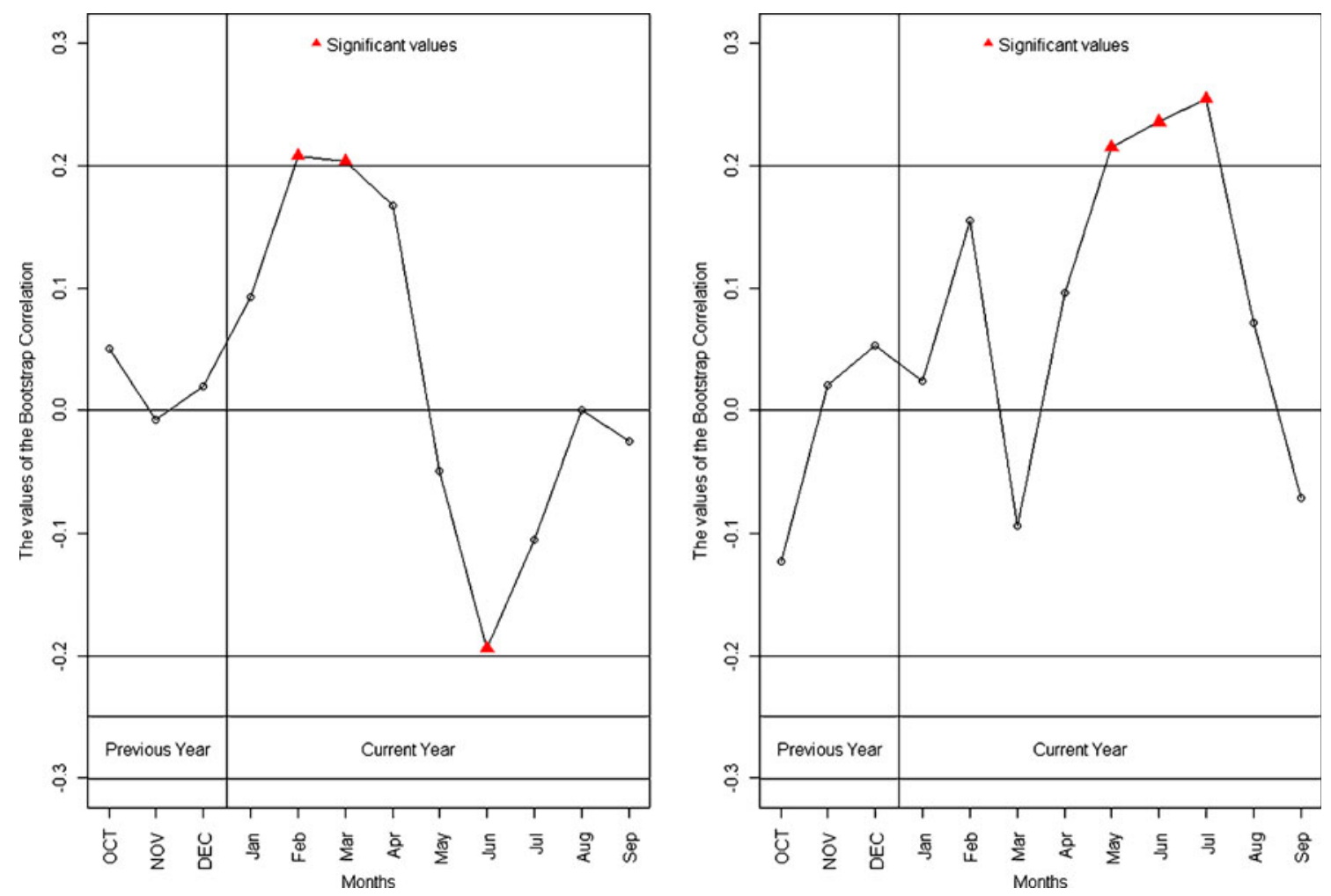

Fig. 4 Response function of the residual chronology with mean monthly temperature and monthly sums of precipitation for tree-ring widths

temperature is $0.41(p<0.001)$. In the next step, the model for the calibrated period was verified using the period 1931-2000. The comparison of calibrated and verified series with actual February-March temperature is presented in Fig. 5. The correlation value for the verification is 0.51 $(p<0.001)$. On the basis of this finding, we calculated the final reconstruction by solving the regression equation for mean value of February-March temperature using: $\mathrm{Y}_{t}=$
Fig. 5 Calibration and verification of the February-March indexes of temperature

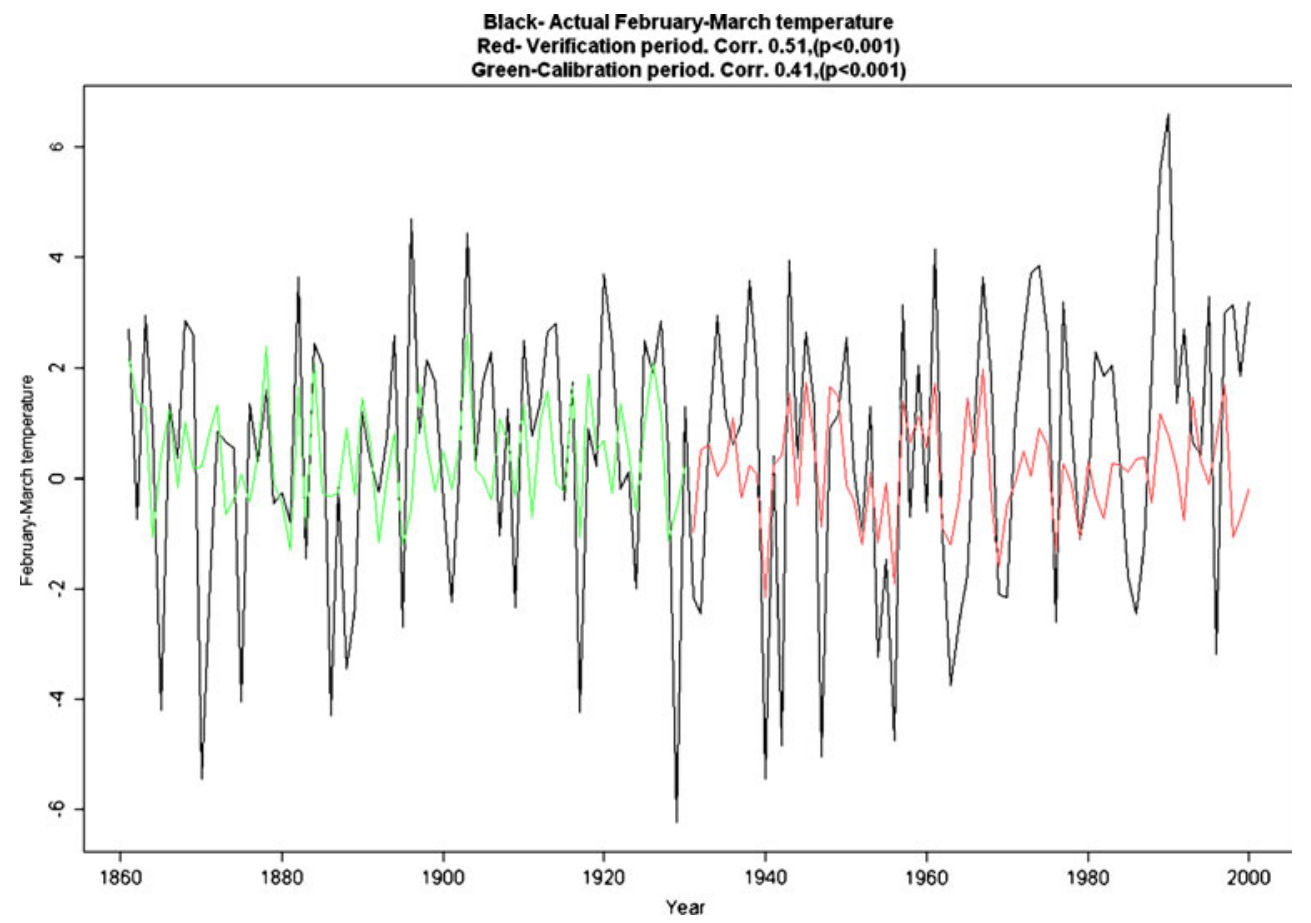


6.244X $\mathrm{X}_{t}-5.937$, where $\mathrm{Y}_{t}$ is reconstructed air temperature in year $t$, and $\mathrm{X}_{t}$ is the indexed tree ring width in a year $t$.

A comparison of the reconstructed and observed FebruaryMarch temperatures reveals a statistically significant correlation coefficient $(p<0.001)$ equal to 0.45 for years $1861-2000$.

In order to analyze long-term changes in winter temperature, the low-pass Hanning filter was applied with a 51-year segment length, and the correlation coefficient for the period $1886-1975$ is $0.63, p<0.001$ (Fig. 6). The analysis of reconstructed indexed values of temperature for mean values in the 51-year moving intervals allows the coldest periods to be determined. These were found to be 1207-1346, 1383-1425, 1455-1482, 1533-1574, $1627-$ 1646, and 1694-1785.

Climate/growth relationships- pointer years

A total of 125 extremely narrow or wide rings were determined in a period 1173-2000. Among these, 57 years were negative (i.e. with narrow rings) and 68 positive (wide rings). Extreme years make up $15.1 \%$ of the total number of all rings $(6.9 \%$ wide rings, $8.2 \%$ narrow rings). Each year is presented on Fig. 7. The occurrence of some of them may be explained by weather conditions (see "Discussion"). Figure 8 presents the number of pointer years in a 50-year time span.

In Table 1, we presented explanations of pointer years determined in period 1581-1676. A total of 16 samples were chosen. Five pointer years with narrow tree ring and early wood were selected. In 1611, the wide rings were observed on 10 samples, in 1622 on 15 samples and in
1645 on 14 samples. A negative reaction was noted in 1616 (12 samples) and in 1624 (16 samples).

Comparison with European chronologies in the context of climate

The KUJAWPOM chronology was compared with chronology from east part of Germany (Brandenburg state), 924 1995 AD (BKIEFERH; Heußner, unpublished) and from Lithuania, 1487-2002 AD (LITHPINUS; Vitas 2008). The common 509-year period of 1487-1995 for each chronology was chosen. The $t$ values for each comparison are: (1) KUJAWPOM - LITHPINUS, $t=8.7$, (2) KUJAWPOM BKIEFERH, $t=13.6$, (3) BKIEFERH - LITHPINUS, $t=3.6$.

\section{Discussion}

Climate/growth relationships

The stability of the climate/growth relationships is one of the most difficult problems in selecting the proper climate parameters. Very often, the significant values for response function coefficients change in different time spans. This is discussed in detail by Schweingruber (1996, pp 518-520). In our research, we obtained significant values for February-March temperature (Fig. 4) in relation to pine growth. This relationship is typical for both Polish lowland as well as for the mountainous regions. The late winter and early spring temperature signal was observed for all the sites in Poland (Zielski et al. 2010), with only minor
Fig. 6 Indexed (green) and actual (red) temperature of February-March filtered by the low-pass filter

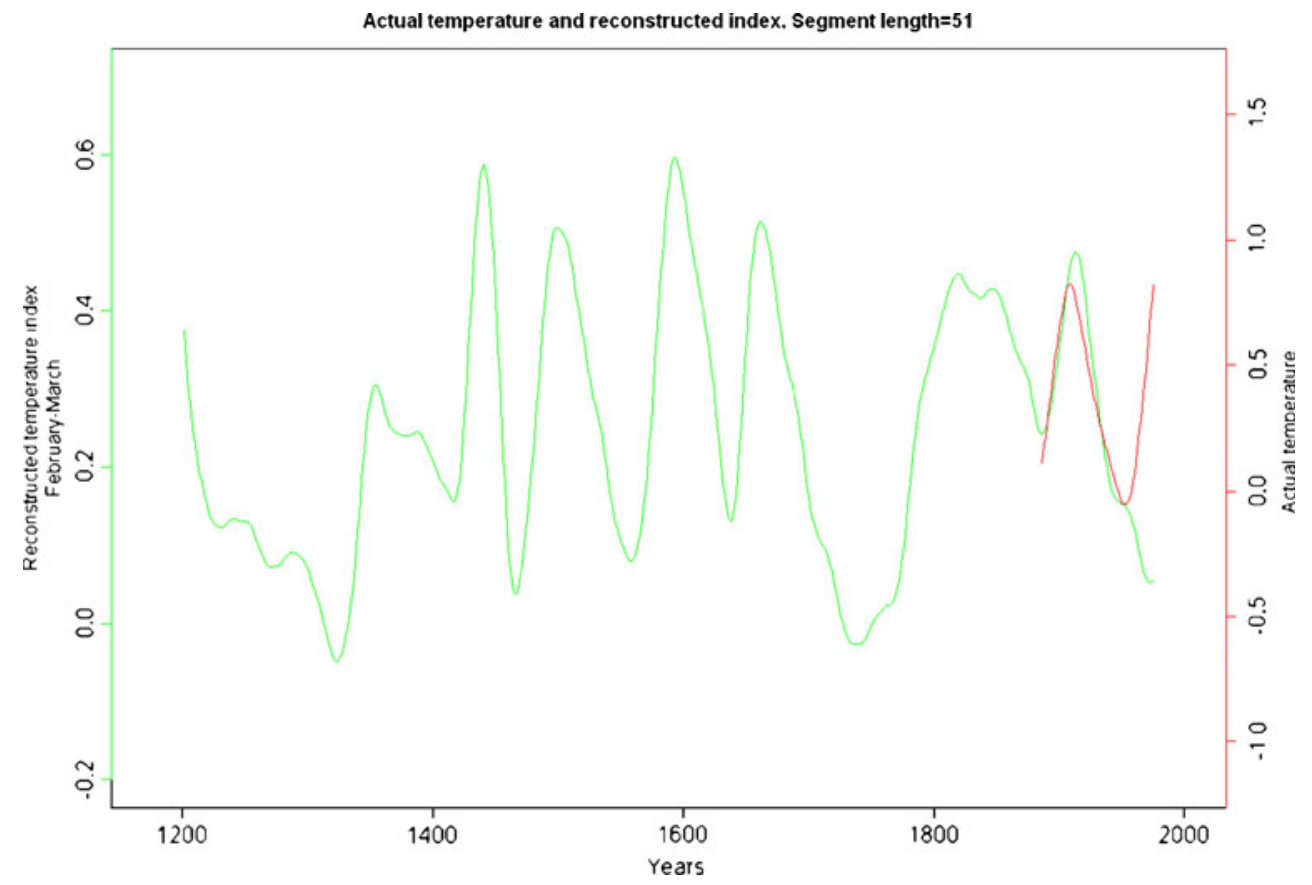


Fig. 7 Pointer years established on the basis of KUJAWPOM chronology
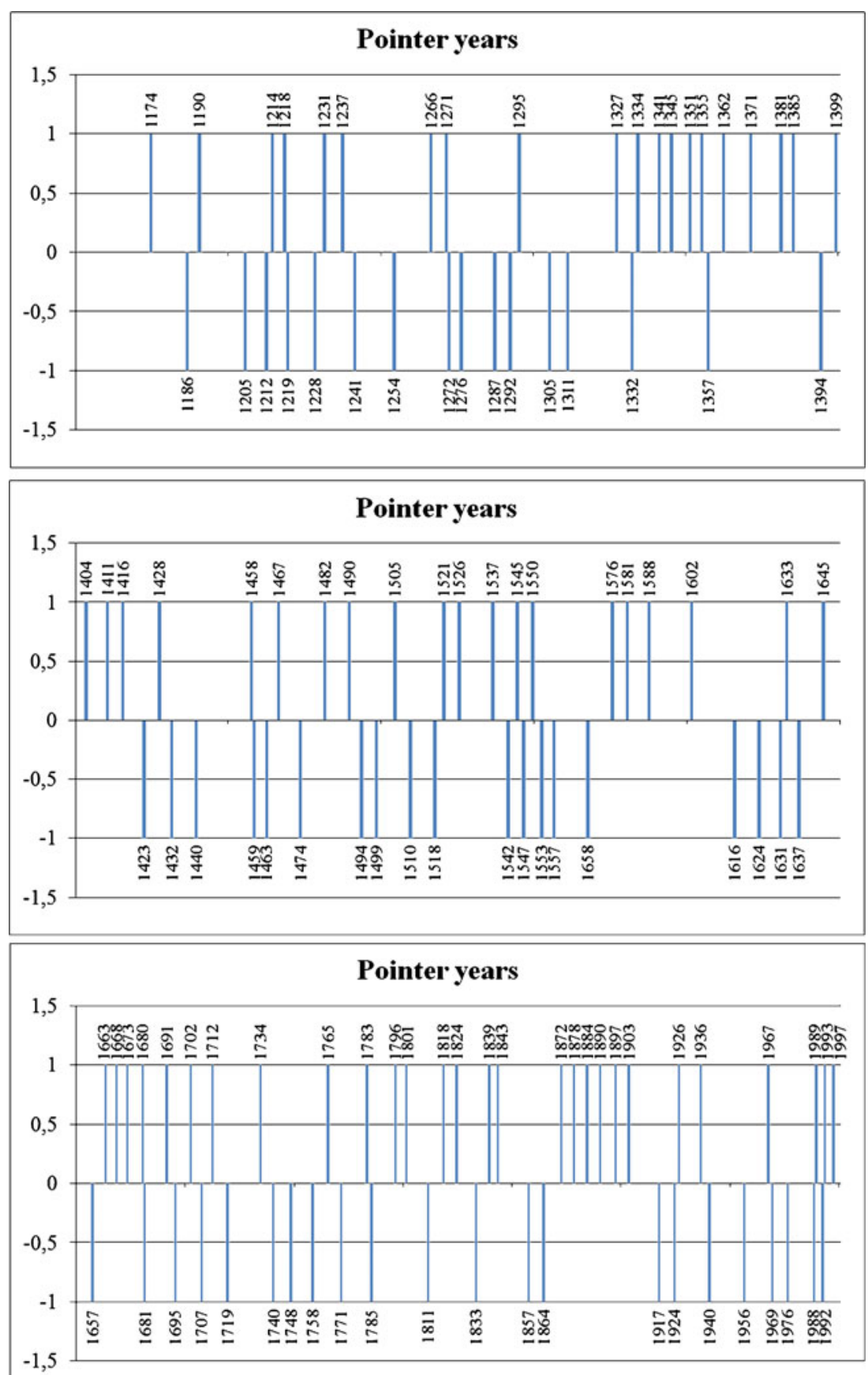

differences reflected in the designated months. For example: (1) in the Torun region, the months vary according to site, and it was February-March, February or March (Zielski 1997; Zielski and Sygit 1998), (2) in north-western Poland from February and beginning of spring (Cedro 2006), (3) in the mountainous with a positive response to warm temperature from February to March (Feliksik and Wilczyński 2000; Wilczyński and Skrzyszewski 2002), and (4) in the Małopolska region, the February-March temperature is also the most stable factor which determines tree growth (Szychowska-Krapiec 2010).

Reconstruction-linear model

Two different approaches were applied: the linear regression and analysis of pointer years. The comparison of actual with reconstructed series shows the significant correlation values (Fig. 5). However, better correlation was achieved for filtered data. A low pass Hanning filter with segment 
Fig. 8 The occurrence of pointer years in 50-year intervals

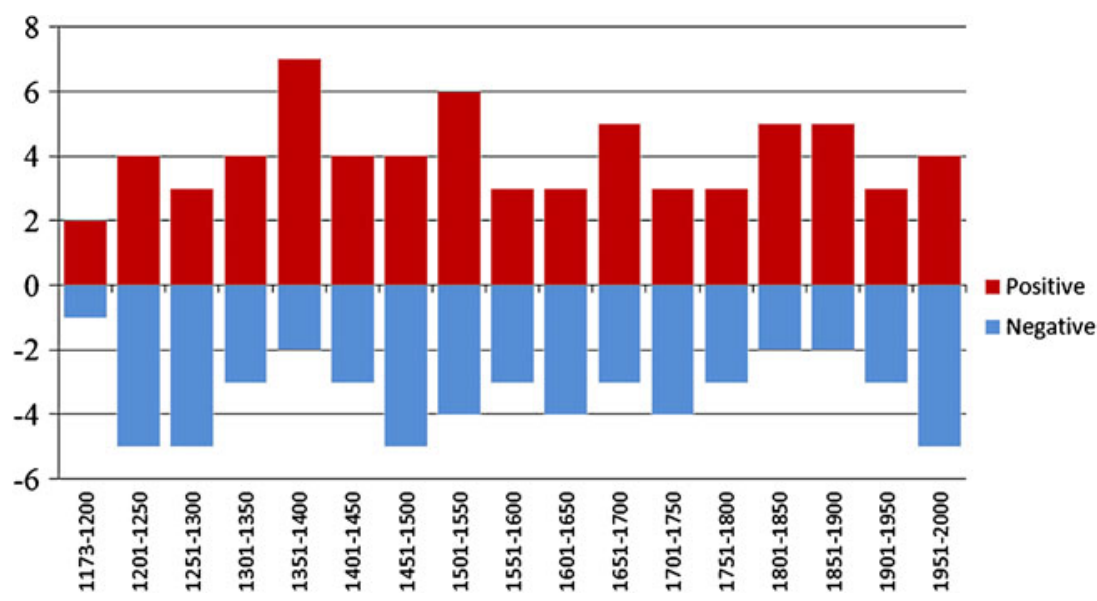

length of 51 years presented high correlation values for reconstructed and raw temperature values (Fig. 6). The first temperature decrease in the reconstructed series was noted in the years 1207-1346. According to Szychowska-Krapiec (2010), in southern Poland the decreasing trend was observed in the years 1220-1320. These years partially overlap with the traditionally accepted time of the Medieval Warm Period, which lasted from 900 to 1300 according to Jones and Mann (2004). Other researchers place the Medieval Warm Epoch in the period 1100-1200 (Bradley 2003). The results presented here for southern Poland, however, suggest that the Medieval Warm Period may have ended by the early thirteenth century.

The detailed time span of the Little Ice Age (LIA) is also relevant. Jones and Mann (2004) summarize that LIA lasted from around 1300-1450 until 1850-1900, with years 15501850 commonly used to delimit the LIA. Independently of the exact time span of LIA, we have registered three periods with lower temperatures: 1533-1574, 1627-1646, and 1694-1785. A long decrease of February-March temperature from 1570 to 1780 was also recognized in pine tree rings from the Małopolska region (southern Poland), and within this period, Szychowska-Krapiec (2010) distinguished two cooler periods: about 1600 and 1730-1740. This indicates that the LIA in Poland ended in the second half of eighteenth century. Comparison with other reconstructions of climate in Poland shows similarities in terms of low late winter-early spring temperature in years 1600-1650, 1760-1775 (Przybylak et al. 2005), and in 1290-1310, 1400-1420, 1600-1650, 1750-1770 (Zielski and Kamiński 2003). Other reconstructions in Poland were carried out for mountainous regions using spruce chronologies (Bednarz 1996; Kaczka 2004; Büntgen et al. 2007). In contrast to the pine reconstructions discussed here, these found strong relationships between spruce growth and summer temperature, thus enabling reconstruction of this parameter. Their reconstruction has a common period overlap with that presented here of 1690-1719 (Bednarz 1996). This period falls during the so-called Mauder Minimum. Combining the two results suggests that Polish temperatures were low in both late winter and summer in this period

Reconstruction-pointer years

The most likely cause of the narrow rings in 1394, 1423, 1459, 1940 and 1976 are late heavy frosts (Fig. 7), as observed and confirmed by historical sources (Wójcik et al. 2001). Even if these years do not coincide with reconstructed cold periods, they bring important information about possible, incidental and extreme weather phenomena. Some of these were observed in the surrounding regions,

Table 1 Pointer years for Koronowo post-Cistercian church and their explanations

\begin{tabular}{llll}
\hline Pointer years & Pfister 1999 & Przybylak et al. 2005 & Other \\
\hline $\begin{array}{lll}\text { Positive } 1611 \\
\text { Negative } 1616\end{array}$ & $\begin{array}{l}\text { Other than climatical } \\
\text { Cold January and February, very warm } \\
\text { and very dry June and July. } \\
\text { Very cold and wet previous July and August. }\end{array}$ & $\begin{array}{c}\text { Very warm summer, } \\
\text { central Poland. }\end{array}$ & $\begin{array}{c}\text { Hot and dry summer in } \\
\text { Slovenia (Čufar et al. 2008) }\end{array}$ \\
$\begin{array}{l}\text { Negative } 1624 \\
\text { Positive } 1645\end{array}$ & Very warm and very dry previous July and August. & $\begin{array}{c}\text { Very warm summer, west } \\
\text { and central Poland. }\end{array}$ & \\
\hline
\end{tabular}


the effects of the cold winter in 1940 were noted in southern Poland by Szychowska-Krapiec (2010) and in Lithuania by Vitas (2008).

We also investigated in detail the shorter period from 1581 to 1676 . The comparison with historical data for central Europe (Pfister 1999) and with multi-proxy reconstructions for Poland (Przybylak et al. 2005) show that precipitation during the vegetation season also plays an important role in determining tree-ring widths. The positive influence of precipitation was observed in May, June and July (Fig. 4). Combination of wide early wood with wide tree-rings and narrow early wood with narrow tree-rings gave promising results in terms of precipitation reconstruction during the vegetation season of current or previous year (Table 1). One of the typical pointer years observed in the central Europe is 1616. According to Pfister (1999), the temperature observed in June and July was high, together with low precipitation totals. Narrow rings were also observed in Slovenia (Čufar et al. 2008) and in northeastern Poland (Szychowska-Krapiec and Krapiec 2005).

\section{European context}

In the European context, comparison of the KUJAWPOM chronology with German and Lithuanian chronologies highlighted stronger similarities to the German one. When we assume that tree growth is determined by weather conditions, the indirect conclusion is that the Polish climate is more comparable with the eastern part of western Europe than with regions located to the east of Poland. The analysis of spruce chronologies from eastern Poland and Lithuania shows that only 2 (the most northeastern) of 45 chronologies have a similar pattern to the Lithuanian one (Koprowski and Vitas 2010). Such differences in spruce increment pattern from Poland and Lithuania confirm the lower similarity of KUJAWPOM chronology to LITHPINUS. SzychowskaKrapiec (2010) studied the teleconnections of the pine chronology from Małopolska. Greater similarities were found with central Germany than with north-eastern Poland (near Lithuania).

\section{Conclusions}

Scot's pine has adapted to differing climatic conditions throughout its range, making the choice of weather parameters that the trees may respond to difficult. Both previous research and the results presented here show that temperature from February to March seems to be one of the most stable factors influencing pine growth. Correlation coefficients in the calibration and validation procedures gave promising results for temperature reconstruction in central Poland based on pine chronologies. The prevailing role of February-March temperature in determining tree growth of different species was also emphasized by Feliksik and Wilczyński (2009). Pointer years, especially a combination of wide and narrow early wood and tree-ring widths, provide significant information about pluvial conditions, and this is supported by historical data from central Europe. In the European context, the Polish chronology is more similar to the German chronology than Lithuanian one.

Acknowledgements We thank Martin Bridge for checking the English version and for comments on the manuscript and Karl-Uwe Heußner for permission to use his chronology. We would like to thank the two anonymous reviewers for their comments that helped to improve the manuscript. The research was supported by the Ministry of Science and Higher Education No. N306018 32/1027 and by the Institute of Ecology and Environment Protection of Nicolaus Copernicus University in Torun, Poland.

Open Access This article is distributed under the terms of the Creative Commons Attribution Noncommercial License which permits any noncommercial use, distribution, and reproduction in any medium, provided the original author(s) and source are credited.

\section{References}

Bednarz Z (1996) June-July temperature variation for the Babia Góra National Park, Southern Poland, for the period 1650-1910. Zeszyty Naukowe Uniwersytetu Jagielońskiego. Prace Geogr 102:523-529

Biondi F, Waikul K (2004) DENDROCLIM 2002: A C++ program for statistical calibration of climate signals in tree-ring chronologies. Comput Geosci 30:303-311

Bradley RS (2003) Presentation. "Climate of the last millenium". HOLOCENE. Working Group Workshop. Bejrkness Centre for Climate Research, August 2003

Bunn AG (2008) A dendrochronology program library in R (dplR). Dendrochronologia 26:115-124

Büntgen U, Frank DC, Kaczka RJ, Verstege A, Zwijacz-Kozica T, Esper J (2007) Growth responses to climate in a multi-species tree-ring network in the Western Carpathian Tatra Mountains, Poland and Slovakia. Tree Physiol 27:689-702

Cedro A (2001) Dependence of radial growth of Pinus sylvestris L. from Western Pomerania on the rainfall and temperature conditions. Geochronometria 20:69-74

Cedro A (2006) Comparative dendroclimatological studies of the impact of temperature and rainfall on Pinus nigra Arnold and Pinus sylvestris in Northwestern Poland. Baltic For 12:110-116

Cook ER, Briffa K, Shiyatov S, Mazepa A, Jones PD (1990) Data analysis. In: Cook ER, Kairiukstis LA (eds) Methods of dendrochronology: applications in the environmental sciences. International Institute for Applied Systems Analysis, Kluwer, Boston, pp 97-162

Čufar K, De Luis M, Eckstein D, Kajfež-Bogataj L (2008) Reconstructing dry and wet summers in SE Slovenia from oak tree-ring series. Int J Biometeorol 52:607-615

R Development Core Team (2007) R: a language and environment for statistical computing. URL: http://www.R-project.org

Esper J, Gärtner H (2001) Interpretation of tree-ring chronologies. Erdkunde 55:277-287

Feliksik E, Wilczyński S (2000) The influence of thermal and pluvial conditions on the radial increment of the Scots pine (Pinus 
sylvestris L.) from the area of Dolny Ślask. Fol For Pol Ser A 42:55-66

Feliksik E, Wilczyński S (2009) The effect of climate on tree-ring chronologies of native and nonnative tree species growing under homogenous site conditions. Geochronometria 33:49-57

Fritts HC (1976) Tree-rings and climate. Academic, London

Gonzales IG (2001) Weiser: a computer program to identify event and pointer years in dendrochronological series. Dendrochronologia 19:239-244

Grissino-Mayer HD (2001) Evaluating crossdating accuracy: a manual and tutorial for the computer program COFECHA. Tree-Ring Res 2:205-221

Jones PD, Mann ME (2004) Climate over past millennia. Rev Geophys 42:1-42

Kaczka RJ (2004) Dendrochronologiczny zapis zmian klimatu Tatr od schyłku epoki lodowcowej (na przykładzie Doliny Gąsienicowej). Prace Geogr 197:89-113

Koprowski M, Vitas A (2010) Growth/climate relationships in treering widths of Picea abies in Lithuania and Poland. In: Przybylak R, Majorowicz J, Brázdil R, Kejna M, (eds) The Polish climate in the European context: an historical overview. Springer, Berlin, pp $327-340$

Meyer FD (1998-1999) Pointer year analysis in dendroecology: a comparison of methods. Dendrochronologia 16-17:193-204

Oppenheim AV, Schafer RW, Buck JR (1999) Discrete-time signal processing, 2nd edn. Prentice-Hall, London

Pfister Ch (1999) Wetternachhersage: 500 Jahre Klimavariationen und Naturkatastrophen (1496-1995). Bern-Stuttgart-Wien

Przybylak R, Majorowicz J, Wójcik G, Zielski A, Chorążyczewski W, Marciniak K, Nowosad W, Oliński P, Syta K (2005) Temperature changes in Poland from the 16th to the 20th centuries. Int $\mathrm{J}$ Climatol 25:773-791

Przybylak R, Majorowicz J, Brázdil R, Kejna M (2010) The Polish climate in the European context: an historical overview. Springer, Berlin

Rinn F (2003) TSAP-Win, Software for tree-ring measurement, analysis and presentation. Rinntech. URL: http://www.rinntech.com

Schweingruber FH (1983) Der Jahrring. Standort, Methodik, Zeit und Klima in der Dendrochronologie. Haupt, Bern

Schweingruber FH (1996) Tree rings and environment. Dendroecology. Birmensdorf. Swiss Federal Institute for Forest, Snow and Landscape Research, Bern
Szychowska-Krąpiec E (2010) Long-term chronologies of pine (Pinus sylvestris L.) and fir (Abies alba Mill.) from the Małopolska Region and their paleoclimatic interpretation. Folia Quat 79

Szychowska-Krąpiec E, Krapiec M (2005) The Scots pine chronology (1582-2004 AD) for the Suwałki Region, NE Poland. Geochronometria 24:41-51

Verzani J (2004) Using R for Introductory statistics

Vitas A (2008) Tree-ring chronology of Scots pine (Pinus sylvestris L.) for Lithuania. Baltic For 14:110-115

Vizi Z, Marciniak K, Przybylak R, Wójcik G (2001) Homogenisation of seasonal and annual air temperature series from Bydgoszcz and Toruń. Annales Universitatis Mariae Curie-Skłodowska LV/ LVI:357-367

Wilczyński S, Skrzyszewski J (2002) Dependence of Scots pine treerings on climatic conditions in Southern Poland (Carpatian Mts.). Electr J Pol Agric Univ (For) 2:1-9

Wójcik G, Przybylak R, Marciniak K, Zielski A, Koprowski M (2001) Extreme yearly increments of trees in Northern Poland from the 12th to the 20th centuries and their relation to climate Eurodendro 2001. Book of abstracts. Gozd Martuljek, Slovenia 6 10.06.2001 (poster)

Zielski A (1997) Uwarunkowania środowiskowe przyrostów radialnych sosny zwyczajnej (Pinus sylvestris L.) w Polsce Północnej na podstawie wielowiekowej chronologii. Wydawnictwo UMK, Toruń

Zielski A, Kamiński P (2003) Możliwości wykorzystania metody dendrochronologicznej do rekonstrukcji klimatu w średniowieczu. In: Krążawski K (ed) Pogranicze polsko-pruskie i krzyżackie. Włocławek-Brodnica, pp 9-25

Zielski A, Krapiec M (2004) Dendrochronologia. Wydawnictwo Naukowe PWN, Warszawa

Zielski A, Sygit W (1998) Wpływ klimatu na przyrost radialny sosny w borach i borach mieszanych na transektach badawczych: klimatycznym (wzdłuż 52 N, 12-13E) i śląskim. In: Breymeyer A, Roo-Zielińska E (eds) Bory sosnowe w gradiencie kontynentalizmu i zanieczyszczeń w Europie Środkowej-badania geoekologiczne, Warszawa. Dokumentacja Geograficzna IGiPZ PAN 13:161-185

Zielski A, Krapiec M, Koprowski M (2010) Dendrochronological data. In: Przybylak R, Majorowicz J, Brázdil R, Kejna M (eds) The Polish climate in the European context: an historical overview. Springer, Berlin, pp 191-217 